\title{
Integrated impact of soil applied nitrogen and foliar applied micronutrients mixture (Gillette) on growth and yield of safflower (Carthamus tinctorius L.) under field conditions
}

\author{
Zahid Ali ${ }^{1}$, Wahid Dino Sipio ${ }^{2}$, Faiza Somroo ${ }^{2}$, Jawed Aslam \\ Khyber $^{2}$, Jay Kumar Soothar², Mahfishan Siyal², Waqar Sahar ${ }^{2}$, \\ Shafiq ur Rehman Memon ${ }^{3}$ and Mukesh Kumar Soothar ${ }^{4 *}$ \\ 1. Department of Agronomy, Sindh Agriculture University Tandojam-Pakistan \\ 2. Department of Plant Breeding and Genetics, Sindh Agriculture University Tandojam-Pakistan \\ 3. College of Resource, Sichuan Agricultural University, 611130 Chengdu P.R-China \\ 4. Farmland Irrigation Research Institute, Chinese Academy of Agricultural Sciences, Xinxiang P.R-China \\ *Corresponding author's email: mukeshksootar@gmail.com \\ Citation
}

Zahid Ali, Wahid Dino Sipio, FaizaSomroo, Jawed Aslam Khyber, Mahfishan Siyal, Waqar Sahar, Jay Kumar Soothar, Shafiq ur Rehman Memon and Mukesh Kumar Soothar. Integrated impact of soil applied nitrogen and foliar applied micronutrients mixture (Gillette) on growth and yield of safflower (Carthamus tinctorius L.) under field conditions. Pure and Applied Biology. Vol. 8, Issue 4, pp2204-2212.

http://dx.doi.org/10.19045/bspab.2019.80166

\begin{tabular}{llll}
\hline \hline Received: 09/05/2019 & Revised: 15/07/2019 & Accepted: 23/07/2019 & Online First: 03/08/2019 \\
\hline \hline
\end{tabular}

\section{Abstract}

Integrated soil nitrogen and foliar application of trace elements could increase crop growth and yield and decrease environmental pollution. In order to explore the impact of soil applied nitrogen and foliar applied micronutrients on safflower growth and yield, a field experiment was conducted at Soil Chemistry Section, Agriculture Research Institute, Tandojam, during Rabi season in 201617.Seven treatments and three replicates were used for each treatment. T1 (control), T2, T3 and T4, T5, T6 and T7 = 50, 100 and $150 \mathrm{~kg} \mathrm{~N}$ ha-1 (soil) $+1250 \mathrm{ml}$ and $2000 \mathrm{ml} \mathrm{ha-1}$ (foliar) were used respectively. The present study revealed that the crop was treated with $\mathrm{N} @ 150 \mathrm{~kg} \mathrm{ha}^{-1}$ (soil) + Gillette (Micronutrients mixture) @ $2000 \mathrm{ml} \mathrm{ha}^{-1}$ (foliar) produced maximum plant population $\left(42.2 \mathrm{~m}^{-2}\right)$, plant height $(126.2 \mathrm{~cm})$, branches plant ${ }^{-1}(11.0)$, seeds capitulum ${ }^{-1}(42.9)$, seed index (1000 seed weight, $44.0 \mathrm{~g})$ and seed yield (2400 kg ha-1) as compared to $\mathrm{N} @ 100$ $\mathrm{kg} \mathrm{ha}^{-1}$ (soil) + Gillette(Micronutrients mixture) @ $2000 \mathrm{ml} \mathrm{ha}^{-1}$ (Foliar) which was recorded plant population $\left(41.1 \mathrm{~m}^{-2}\right)$, plant height $(124.8 \mathrm{~cm})$, branches plant ${ }^{-1}(10.0)$, seeds capitulum ${ }^{-}$ ${ }^{1}$ (41.9), seed index (43.0 g), and seed yield $\left(2350 \mathrm{~kg} \mathrm{ha}^{-1}\right)$. While the lowest results for all parameters were recorded in control. It is obvious from the results that $\mathrm{N} @ 100 \mathrm{~kg} \mathrm{ha}^{-1}$ (soil) + Gillette (Micronutrients mixture) @ $2000 \mathrm{ml} \mathrm{ha}^{-1}$ (Foliar) recorded optimum results due to medium dose of nitrogen and non-significant differences (LSD@5\%) with T7 and T4 where highest dose of nitrogen was applied.

Keywords: Foliar application; Growth; Micronutrients mixture; Safflower 


\section{Introduction}

Safflower (Carthamus tinctorius L.) is an oilseed crop in the asteraceae plant family and believed as one of the oldest cultivated crops [1]. The crop was originally grown for the flowers that were used in making red and yellow dyes for clothing and food preparation. Today this crop supplies oil, meal, birdseed, and foots (residue from oil processing) for the food and industrial products markets, although this crop is now primarily grown for the oil. Safflower is an annual species in the same plant family as sunflower. This crop is adapted to dry land or irrigated cropping systems [2]. Apart from the use as edible oil, safflower is a crop for multiple purposes. Florets as well as seeds are used for cosmetic products and medicinal purposes in traditional Chinese medicine. Seeds are also used as birdseed [3]. In Pakistan, the commercial varieties of safflower are Gilla, US-10, S-208 (spiny), Thori-78 and Pawari-95 (spineless). The crop is a suitable oilseed in the arid and semiarid region and well grown in the sunny and high temperature condition. In addition, it is able to meet its water requirements by drawing moisture from deep in the subsoil. It also could improve the overall Nitrogen (N) use efficiency of cropping systems and minimize nitrate leaching to groundwater [4]. Numerous important factors influence the crop yield directly which included soil fertility, macro and micronutrient availability in soil, input application and crop management. The crop production can be increased either by bringing more area under cultivation or by increasing its yield per unit area. Under the present situation, the more suitable option is to obtain higher yield per unit area. The deficiency of micronutrients, particularly Zinc (Zn), Boron (B), Iron (Fe), Copper $(\mathrm{Cu})$, Calcium $(\mathrm{Ca})$, Manganese $(\mathrm{Mn})$, Magnesium $(\mathrm{Mg})$ cause poor crop yields and due to soil inadequacy for these nutrients, the crop plants are losing resistance against diseases [5]. However, it is generally known that $\mathrm{N}$ is essential nutrient for all the crops growth and production including safflower [6]. [7] Reported that safflower responded to nitrogen at the rate of $120 \mathrm{~kg}$ ha1. At the same time some researchers have reported that nitrogen loss through hydrological and gaseous pathways $[8,9]$. Nitrogen leaching is considered to be the dominant cause of increasing $\mathrm{NO}_{3}$ concentration in groundwater. Higher levels of nitrogen application could lead $\mathrm{N}$ loss in the form of ammonia $\left(\mathrm{NH}_{4}\right)$, leach down to make ground water contaminated and economic loss of grower. For such reasons, the reduced doses of $\mathrm{N}$ fertilizer with the application of bio-fertilizers can decrease the need of synthetic fertilizers and also contribute to reduce the negative effects, improve soil fertility, soil properties and augment crop yield. Moreover bio-fertilizers are important to ameliorate environmental pollution and deterioration of nature.

Micronutrients are important for plant development, yield and participating in enzyme activities [10]. They are required in very minute quantity. In the case of their deficiency crop growth and yield inhibited $[11,12]$. Similarly, Boron is another nonmetal micronutrient essential required for proper plant growth and seed development [13] and B availability decreases with increasing soil $\mathrm{pH}$, thus it is often inadequately available in calcareous soils [14]. The B deficiency affects plant growing points such as, buds, fruits, flowers, root tips (Weil and Brady), necrosis of internal tissues, turning of the leaves colour [15]. The lack of Iron ( $\mathrm{Fe})$ cause chlorosis, leaf becomes white and yellow $[16,17]$. Many studies revealed the pivotal role of micronutrients on different crops. For example, [18] applied micronutrients in spray form along with cropping system in safflower in Iran. They revealed that foliar application of micronutrients ( $\mathrm{Zn}$ and $\mathrm{Mn}$ ) significantly increases number of seeds per head, number of heads per plant, 1000 seed weight, seed yield and biological yield. Generally, the fertilizers are applied by broadcasting and foliar application. Keeping the above views in mind, we hypothesize that, integrated soil nitrogen and foliar application of trace elements will increase crop growth and 
yield and decrease environmental pollution [19].

\section{Materials and methods}

A field experiment was conducted to investigate the integrated effect of trace elements by foliar application safflower growth and yield. The experiment was carried out at the experimental field of Soil Chemistry Section, Agriculture Research Institute, Tandojam in the year 2016-2017 with seven treatments following three replication for each treatment in randomized complete block design (RCBD) having net plot size of $3.5 \mathrm{~m} \times 3.0 \mathrm{~m}\left(10.5 \mathrm{~m}^{2}\right)$. The seed of safflower variety Thori-78 was sown with the help of single row hand drill. The treatment details are as under:T1= Control (No $\mathrm{N}$ and micronutrient mixture), T2, T3 and T4=N@50,100 and $150 \mathrm{~kg} \mathrm{ha}^{-1}$ (soil) + Gillette (Micronutrients mixture) @ 1250 $\mathrm{ml} \mathrm{ha}^{-1}$ (Foliar), T5, T6 and T7= N @ 50, 100 and150 kg ha-1 (soil) + Gillette (Micronutrients mixture) @ $2000 \mathrm{ml} \mathrm{ha}^{-1}$ (Foliar) were applied respectively. Gillette is the mixture of micronutrients. This mixture contains micronutrients; iron, boron, magnesium, copper and zinc. The recommended dose of $\mathrm{P}\left(65 \mathrm{~kg} \mathrm{ha}^{-1}\right)$ and $\mathrm{K}$ $\left(25 \mathrm{~kg} \mathrm{ha}^{-1}\right)$ was applied in all the treatments uniformly including control. The micronutrients were applied as foliar treatment after 100 and 130 days after sowing. All $\mathrm{P}$ (as mono ammonium phosphate) and $1 / 3^{\text {rd }}$ of $N$ (as urea) was applied at the time of sowing and remaining $\mathrm{N}$ was applied in two splits at $1^{\text {st }}$ and at $2^{\text {nd }}$ irrigation respectively. For the agronomical observations, five plant from each plot were randomly selected and tagged. After completion of observations on growth parameters, and when crop matures, the labelled plants were harvested manually and tied in small bundles, and were shifted to threshing yard. Threshing was performed manually; the grains were collected carefully to count and record weight. The following parameters were recorded; Plant population $\left(\mathrm{m}^{-2}\right)$, Plant height $(\mathrm{cm})$, Branches plant ${ }^{-1}$, Capitula plant $^{-1}$, Seeds Capitulum $^{-1}$, Seed weight plant $^{-1}(\mathrm{~g})$, Seed index (1000- seed weight, g) and Seed yield $\left(\mathrm{kg} \mathrm{ha}^{-1}\right)$.

\section{Statistical analysis}

The data was subjected to statistical analysis using Statistix 8.1 computer software [20]. The differences among the treatments means was compared by the LSD test.

\section{Results}

The field experiment was carried out to investigate the integrated effect of micronutrients by foliar application on growth and yield of safflower. The results are presented in the following tables (1-3) and their analysis of variance. The results on individual character is given below:

\section{Plant population $\left(\mathrm{m}^{-2}\right)$}

The results regarding plant population (m${ }^{2}$ ) as affected by soil applied nitrogen and foliar applied micronutrients mixture (Gillette) on growth and yield of safflower are presented in table 1 and its Analysis of variance. The results had significant effect on plant population $\left(\mathrm{m}^{-2}\right)(\mathrm{P}>0.05)$. The results revealed that the maximum plant population $\left(42.2 \mathrm{~m}^{-2}\right)$ was observed under $\mathrm{N}$ @ $150 \mathrm{~kg} \mathrm{ha}{ }^{-1}$ (soil) + Gillette (Micronutrients mixture) @ $2000 \mathrm{ml} \mathrm{ha}^{-1}$ (Foliar) as compared to $\mathrm{N} @ 100 \mathrm{~kg} \mathrm{ha}^{-1}$ (soil) + Gillette (Micronutrients mixture) @ $2000 \mathrm{ml} \mathrm{ha}^{-1}$ (Foliar) which was recorded $\left(41.1 \mathrm{~m}^{-2}\right)$ plant population. The crop was treated with $\mathrm{N} @ 150 \mathrm{~kg} \mathrm{ha}^{-1}$ (soil) + Gillette (Micronutrients mixture) @ 1250 $\mathrm{ml} \mathrm{ha}^{-1}$ (Foliar) produced $\left(40.4 \mathrm{~m}^{-2}\right)$ plant population. The results further indicated that the crop was treated with N @ $100 \mathrm{~kg}$ ha $^{-1}$ (soil) + Gillette (Micronutrients mixture)@ $1250 \mathrm{ml} \mathrm{ha}^{-1}$ (Foliar) was observed $\left(33.9 \mathrm{~m}^{-2}\right)$ plant population. The crop was treated with $\mathrm{N} @ 50 \mathrm{~kg} \mathrm{ha}^{-1}$ (soil) + Gillette (Micronutrients mixture) @ 2000 $\mathrm{ml} \mathrm{ha}^{-1}$ (Foliar) was noted $\left(32.0 \mathrm{~m}^{-2}\right)$ plant population. Whereas the lowest plant population $\left(22.4 \mathrm{~m}^{-2}\right)$ was showed in control treatment. It is clear from the results that N@100 kg ha ${ }^{-1}$ (soil)+Gillette (Micronutrients mixture) @ $2000 \mathrm{ml} \mathrm{ha}^{-1}$ (Foliar) recorded optimum results due to medium dose of nitrogen and nonsignificant differences (LSD@5\%) with T7 
and T4 where highest dose of nitrogen was applied.

\section{Plant height (cm)}

The results pertaining to plant height $(\mathrm{cm})$ as affected by soil applied nitrogen and foliar applied micronutrients mixture (Gillette) on growth and yield of safflower are presented in table 1 . The results had significant effect on plant height $(\mathrm{cm})$. The data should that the maximum plant height $(126.2 \mathrm{~cm})$ was observed under N @ 150 $\mathrm{kg} \mathrm{ha}^{-1}$ (soil) + Gillette (Micronutrients mixture) @ $2000 \mathrm{ml} \mathrm{ha}^{-1}$ (Foliar) as compared to $\mathrm{N} @ 100 \mathrm{~kg} \mathrm{ha}^{-1}$ (soil) + Gillette (Micronutrients mixture) @ 2000 $\mathrm{ml} \mathrm{ha}^{-1}$ (Foliar) which was recorded (124.8 $\mathrm{cm})$ plant height. The crop was treated with $\mathrm{N} @ 150 \mathrm{~kg} \mathrm{ha}^{-1}$ (soil) + Gillette (Micronutrients mixture) @ $1250 \mathrm{ml} \mathrm{ha}^{-1}$ (Foliar) produced $(121.1 \mathrm{~cm})$ plant height. The results further indicated that the crop was treated with $\mathrm{N} @ 100 \mathrm{~kg} \mathrm{ha}^{-1}$ (soil) + Gillette (Micronutrients mixture) @ 1250 $\mathrm{ml} \mathrm{ha}^{-1}$ (Foliar) was observed $(113.5 \mathrm{~cm})$ plant height. Whereas the lowest plant height $(96.1 \mathrm{~cm})$ was noted from control treatment. It is clear from the results that $\mathrm{N}$ @ $100 \mathrm{~kg} \mathrm{ha}$ (soil) + Gillette (Micronutrients mixture) @ $2000 \mathrm{ml} \mathrm{ha}^{-1}$ (Foliar) recorded optimum results due to medium dose of nitrogen and nonsignificant differences (LSD@5\%) with T7 and $\mathrm{T} 4$ where highest dose of nitrogen was applied.

\section{Branches plant ${ }^{-1}$}

The data about branches plant ${ }^{-1}$ as affected by soil applied nitrogen and foliar applied micronutrients mixture (Gillette) on growth and yield of safflower are presented in table 1. The results had significant effect on branches plant ${ }^{-1}$. The results indicated that the maximum branches plant ${ }^{-1}(11.0)$ was observed under N@150 kg ha ${ }^{-1}$ (soil)+ Gillette (Micronutrients mixture) @ 2000 $\mathrm{ml} \mathrm{ha}^{-1}$ (Foliar) as compared to N@100 kg ha $^{-1}$ (soil) + Gillette (Micronutrients mixture) @ $2000 \mathrm{ml} \mathrm{ha}^{-1}$ (Foliar)which was recorded (10.0) branches plant ${ }^{-1}$. The crop was treated with $\mathrm{N} @ 150 \mathrm{~kg} \mathrm{ha}^{-1}$ (soil) + Gillette (Micronutrients mixture) @1250 $\mathrm{ml} \mathrm{ha}^{-1}$ (Foliar) produced (9.0) branches plant $^{-1}$. The results further indicated that the crop was treated with $\mathrm{N} @ 100 \mathrm{~kg} \mathrm{ha}^{-1}$ (soil) + Gillette (Micronutrients mixture) @ 1250 $\mathrm{ml} \mathrm{ha}^{-1}$ (Foliar) was recorded (8.4)branches plant $^{-1}$, however the crop treated with N @ $100 \mathrm{Kg} \mathrm{ha}^{-1}+$ Gillette (Micronutrients mixture) @ $1250 \mathrm{ml} \mathrm{ha}{ }^{-1}$ (Foliar) was observed (8.0) branches plant ${ }^{-1}$. Whereas, the lowest branches plant ${ }^{-1}$ (7.0) was noted from control treatment. It is clear from the results that $\mathrm{N} @ 100 \mathrm{~kg} \mathrm{ha}^{-1}$ (soil)+ Gillette (Micronutrients mixture) @ $2000 \mathrm{ml} \mathrm{ha}^{-1}$ (Foliar) recorded optimum results due to medium dose of nitrogen and nonsignificant differences (LSD@5\%) with T7 and T4 where highest dose of nitrogen was applied.

\section{Capitula plant ${ }^{-1}$}

The data regarding capitula plant $^{-1}$ as affected by soil applied nitrogen and foliar applied micronutrients mixture (Gillette) on growth and yield of safflower are presented in table 2. The results had significant effect on capitula plant ${ }^{-1}$. The results suggested that the maximum capitula plant ${ }^{-1}$ (87.0) was observed under $\mathrm{N} @ 150 \mathrm{~kg} \mathrm{ha}^{-1}$ (soil) + Gillette (Micronutrients mixture) @ 2000 $\mathrm{ml} \mathrm{ha}^{-1}$ (Foliar) as compared to N @ $100 \mathrm{~kg}$ ha $^{-1}$ (soil) + Gillette (Micronutrients mixture)@ $2000 \mathrm{ml} \mathrm{ha}^{-1}$ (Foliar) which was recorded (85.0) capitula plant ${ }^{-1}$. The crop was treated with N@150 kg ha ${ }^{-1}$ (soil) + Gillette (Micronutrients mixture) @ 1250ml ha $^{-1}$ (Foliar) produced (82.0) capitula plant 1 . The results further indicated that the crop was treated with $\mathrm{N} @ 50 \mathrm{~kg} \mathrm{ha}^{-1}$ (soil) + Gillette (Micronutrients mixture) @ 2000 $\mathrm{ml} \mathrm{ha} \mathrm{ha}^{-1}$ (Foliar) was observed (77.0) capitula plant ${ }^{-1}$.However, the crop was treated with N@100 kg ha ${ }^{-1}$ (soil)+Gillette Micronutrients mixture) @ $1250 \mathrm{ml} \mathrm{ha}^{-}$ ${ }^{1}$ (Foliar) was observed (79.0) capitula plant ${ }^{-}$ ${ }^{1}$ Whereas the lowest capitula plant ${ }^{-1}$ (73.0) was noted from control treatment. It is clear from the results that $\mathrm{N} @ 100 \mathrm{~kg} \mathrm{ha}^{-1}$ (soil) + Gillette (Micronutrients mixture) @ 2000 $\mathrm{ml} \mathrm{ha} \mathrm{h}^{-1}$ (Foliar) recorded optimum results due to medium dose of nitrogen and nonsignificant differences (LSD@5\%) with T7 
and T4 where highest dose of nitrogen was applied.

Table 1. Plant population $\left(\mathrm{m}^{-2}\right)$ and plant height of safflower as affected by nitrogen and micronutrients mixture (Gillette)

\begin{tabular}{|c|c|c|c|}
\hline \multirow[b]{2}{*}{ Treatments } & \multicolumn{3}{|c|}{ Mean } \\
\hline & $\begin{array}{c}\text { Plant } \\
\text { population } \\
\left(\mathbf{m}^{-2}\right)\end{array}$ & $\begin{array}{c}\text { Plant height } \\
(\mathrm{cm})\end{array}$ & $\begin{array}{l}\text { Branches } \\
\text { plant }^{-1}\end{array}$ \\
\hline $\mathrm{T}_{1}=$ Control (No N and micronutrient) & $22.4 \mathrm{D}$ & $96.1 \mathrm{C}$ & $7.0 \mathrm{E}$ \\
\hline $\mathrm{T}_{2}=\mathrm{N} @ 50 \mathrm{~kg} \mathrm{ha}{ }^{-1}+$ Gillette @ $1250 \mathrm{ml} \mathrm{ha}^{-1}$ & $25.3 \mathrm{C}$ & $100.8 \mathrm{C}$ & $7.3 \mathrm{DE}$ \\
\hline $\begin{array}{c}\mathrm{T}_{3}=\mathrm{N} @ 100 \mathrm{~kg} \mathrm{ha}^{-1}+\text { Gillette@ } 1250 \mathrm{ml} \\
\mathrm{ha}^{-1}\end{array}$ & $33.9 \mathrm{~B}$ & $113.5 \mathrm{~B}$ & 8.0 CDE \\
\hline $\begin{array}{c}\mathrm{T}_{4}=\mathrm{N} @ 150 \mathrm{~kg} \mathrm{ha}^{-1}+\text { Gillette@ } 1250 \mathrm{ml} \\
\mathrm{ha}^{-1}\end{array}$ & $40.4 \mathrm{~A}$ & $121.8 \mathrm{~A}$ & $9.0 \mathrm{BC}$ \\
\hline $\mathrm{T}_{5}=\mathrm{N} @ 50 \mathrm{~kg} \mathrm{ha}^{-1}+$ Gillette $@ 2000 \mathrm{ml} \mathrm{ha}^{-1}$ & $32.0 \mathrm{~B}$ & $109.1 \mathrm{~B}$ & $8.4 \mathrm{CD}$ \\
\hline $\begin{array}{c}\mathrm{T}_{6}=\mathrm{N} @ 100 \mathrm{~kg} \mathrm{ha}^{-1}+\text { Gillette } @ 2000 \mathrm{ml} \\
\mathrm{ha}^{-1}\end{array}$ & $41.1 \mathrm{~A}$ & $124.8 \mathrm{~A}$ & $10.0 \mathrm{AB}$ \\
\hline 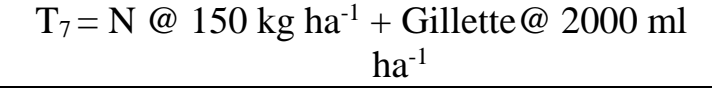 & $42.2 \mathrm{~A}$ & $126.2 \mathrm{~A}$ & $11.0 \mathrm{~A}$ \\
\hline
\end{tabular}

\section{Seeds capitulum ${ }^{-1}$}

The results regarding seeds capitulum ${ }^{-1}$ as affected by soil applied nitrogen and foliar applied micronutrients mixture (Gillette) on growth and yield of safflower are presented in table 2. The results had significant effect on seeds capitulum ${ }^{-1}$. The results revealed that the maximum seeds capitulum ${ }^{-1}$ (42.9 g) was observed under $\mathrm{N} @ 150 \mathrm{~kg} \mathrm{ha}^{-1}$ (soil)+Gillette (Micronutrients mixture) @ $2000 \mathrm{ml} \mathrm{ha}^{-1}$ (Foliar) as compared to N@ $100 \mathrm{~kg} \mathrm{ha}^{-1}$ (soil) + Gillette (Micronutrients mixture)@ $2000 \mathrm{ml} \mathrm{ha}^{-1}$ (Foliar) which was recorded $(41.9 \mathrm{~g})$ seeds capitulum ${ }^{-1}$. The crop was treated with $\mathrm{N} @ 150 \mathrm{~kg} \mathrm{ha}^{-1}$ (soil) + Gillette (Micronutrients mixture) @ 1250 $\mathrm{ml} \mathrm{ha}^{-1}$ (Foliar) produced (40.7 g) seed index. The results further indicated that the crop was treated with $\mathrm{N} @ 100 \mathrm{~kg} \mathrm{ha}^{-1}$ (soil) + Gillette (Micronutrients mixture) @ 1250 $\mathrm{ml} \mathrm{ha}^{-1}$ (Foliar) was observed (37.0 g)seeds capitulum $^{-1}$. Whereas the lowest seeds capitulum $^{-1}(24.8 \mathrm{~g})$ was noted from control treatment. It is clear from the results that $\mathrm{N}$ @ $100 \mathrm{~kg} \mathrm{ha}{ }^{-1}$ (soil) + Gillette (Micronutrients mixture) @ $2000 \mathrm{ml} \mathrm{ha}^{-1}$ (Foliar) recorded optimum results due to medium dose of nitrogen and nonsignificant differences (LSD@5\%) with T7 and T4 where highest dose of nitrogen was applied.

\section{Seed weight plant $^{-1}(\mathrm{~g})$}

The results regarding seed weight plant $^{-1}$ as affected by soil applied nitrogen and foliar applied micronutrients mixture (Gillette) on growth and yield of safflower are presented in table 2. The results had significant effect on seed weight plant ${ }^{-1}$. The results revealed that the maximum seed weight plant $^{-1}$ (164.2 g) was observed under N @ 150 kg ha $^{-1}$ (soil) + Gillette (Micronutrients mixture) @ $2000 \mathrm{ml} \mathrm{ha}^{-1}$ (Foliar) as compared to $\mathrm{N} @ 100 \mathrm{~kg} \mathrm{ha}^{-1}$ (soil) + Gillette (Micronutrients mixture) @ 2000 $\mathrm{ml} \mathrm{ha}^{-1}$ (Foliar) which was recorded (153.4) seed weight plant ${ }^{-1}$. The crop was treated with N@150 kg ha ${ }^{-1}$ (soil) + Gillette (Micronutrients mixture) @ $1250 \mathrm{ml} \mathrm{ha}^{-1}$ (Foliar) produced (131.7 g) seed weight plant $^{-1}$. The results further indicated that the crop was treated with $\mathrm{N} @ 50 \mathrm{~kg} \mathrm{ha}^{-1}$ (soil) + Gillette (Micronutrients mixture) @ 2000 $\mathrm{ml} \mathrm{ha}^{-1}$ (Foliar) was observed (116.9 g)seed weight plant $^{-1}$, however the crop was treated with N@100 kg ha ${ }^{-1}$ (soil)+Gillette (Micronutrients mixture) @1250 ml ha ${ }^{-1}$ (Foliar) was observed (111.3 g) seed weight plant $^{-1}$, Whereas the lowest seed weight plant $^{-1}$ (70.7 g) was noted from control 
treatment. It is clear from the results that $\mathrm{N}$ @ $100 \mathrm{~kg} \mathrm{ha}$ (soil) + Gillette (Micronutrients mixture) @ $2000 \mathrm{ml} \mathrm{ha}^{-1}$ (Foliar) recorded optimum results due to medium dose of nitrogen and nonsignificant differences (LSD@5\%) with T7 and T4 where highest dose of nitrogen was applied.

Table 2. Capitula plant ${ }^{-1}$, seed capitulum ${ }^{-1}$ and seed weight plant $^{-1}$ (g) of safflower as affected by nitrogen and micronutrients mixture (Gillette)

\begin{tabular}{|c|c|c|c|}
\hline \multirow[b]{2}{*}{ Treatments } & \multicolumn{3}{|c|}{ Mean } \\
\hline & Capitula plant $^{-1}$ & $\begin{array}{c}\text { Seeds } \\
\text { capitulum-1 }\end{array}$ & $\begin{array}{l}\text { Seed weight } \\
\text { plant }^{-1}(g)\end{array}$ \\
\hline $\mathrm{T}_{1}=$ Control (No N and micronutrient) & $73.0 \mathrm{G}$ & $24.8 \mathrm{~F}$ & $70.7 \mathrm{~F}$ \\
\hline $\mathrm{T}_{2}=\mathrm{N} @ 50 \mathrm{~kg} \mathrm{ha}^{-1}+$ Gillette@ $1250 \mathrm{ml} \mathrm{ha}^{-1}$ & $75.0 \mathrm{~F}$ & $27.5 \mathrm{E}$ & $81.1 \mathrm{E}$ \\
\hline $\begin{array}{c}\mathrm{T}_{3}=\mathrm{N} @ 100 \mathrm{~kg} \mathrm{ha}^{-1}+\text { Gillette@ } 1250 \mathrm{ml} \\
\mathrm{ha}^{-1}\end{array}$ & $79.0 \mathrm{D}$ & $37.0 \mathrm{C}$ & 111.3 D \\
\hline $\begin{array}{c}\mathrm{T}_{4}=\mathrm{N} @ 150 \mathrm{~kg} \mathrm{ha}^{-1}+\text { Gillette@ } @ 1250 \mathrm{ml} \\
\mathrm{ha}^{-1}\end{array}$ & $82.0 \mathrm{C}$ & $40.7 \mathrm{~B}$ & $131.7 \mathrm{C}$ \\
\hline $\mathrm{T}_{5}=\mathrm{N} @ 50 \mathrm{~kg} \mathrm{ha}^{-1}+$ Gillette@ $2000 \mathrm{ml} \mathrm{ha}^{-1}$ & $77.0 \mathrm{C}$ & $33.1 \mathrm{D}$ & $116.9 \mathrm{D}$ \\
\hline $\begin{array}{c}\mathrm{T}_{6}=\mathrm{N} @ 100 \mathrm{~kg} \mathrm{ha}^{-1}+\text { Gillette } @ 2000 \mathrm{ml} \\
\mathrm{ha}^{-1}\end{array}$ & $85.0 \mathrm{~B}$ & $41.9 \mathrm{AB}$ & $153.4 \mathrm{~B}$ \\
\hline $\begin{array}{c}\mathrm{T}_{7}=\mathrm{N} @ 150 \mathrm{~kg} \mathrm{ha}^{-1}+\text { Gillette@ } 2000 \mathrm{ml} \\
\mathrm{ha}^{-1}\end{array}$ & $87.0 \mathrm{~A}$ & $42.9 \mathrm{~A}$ & $164.2 \mathrm{~A}$ \\
\hline
\end{tabular}

\section{Seed index (1000-seed weight, g)}

The data in relation to seed index $(\mathrm{g})$ as affected by soil applied nitrogen and foliar applied micronutrients mixture (Gillette) on growth and yield of safflower are presented in table 3 . The results had significant effect on seed index $(\mathrm{g})$. The results illustrated that the maximum seed index $(44.0 \mathrm{~g})$ was observed in T7 at the rate of N @ $150 \mathrm{~kg}$ ha $^{-1}$ (soil) + Gillette (Micronutrients mixture) @ $2000 \mathrm{ml} \mathrm{ha}^{-1}$ (Foliar) as compared to $\mathrm{N} @ 100 \mathrm{~kg} \mathrm{ha}^{-1}$ (soil) + Gillette (Micronutrients mixture) @ 2000 $\mathrm{ml} \mathrm{ha}^{-1}$ (Foliar) which was recorded $(43.0 \mathrm{~g})$ seed index. The crop was treated with N @ $150 \mathrm{~kg} \mathrm{ha}^{-1}$ (soil) + Gillette (Micronutrients mixture) @ $1250 \mathrm{ml} \mathrm{ha}^{-1}$ (Foliar) produced $(42.0 \mathrm{~g})$ seed index. The results further indicated that the crop was treated with $\mathrm{N}$ @ $100 \mathrm{~kg} \mathrm{ha}$ (soil) + Gillette (Micronutrients mixture) @ $1250 \mathrm{ml} \mathrm{ha}^{-1}$ (Foliar) was observed (40.0 g)seed index (T3). Whereas the lowest seed weight plant $^{-}$ ${ }^{1}$ (39.0 g) was noted from control treatment $\left(\mathrm{T}_{1}\right)$. It is clear from the results that $\mathrm{N} @$ $100 \mathrm{~kg} \mathrm{ha}^{-1}$ (soil) + Gillette (Micronutrients mixture)@ $2000 \mathrm{ml} \mathrm{ha}^{-1}$ (Foliar) recorded optimum results due to medium dose of nitrogen and non-significant differences
(LSD@5\%) with T7 and T4 where highest dose of nitrogen was applied.

\section{Seed yield $\left(\mathrm{kg} \mathrm{ha}^{-1}\right)$}

The results regarding seed yield $\left(\mathrm{kg} \mathrm{ha}^{-1}\right)$ as affected by soil applied nitrogen and foliar applied micronutrients mixture (Gillette) on growth and yield of safflower are presented in table 3 . The results had significant effect on seed yield $\left(\mathrm{kg} \mathrm{ha}^{-1}\right)$. The results revealed that the maximum seed yield $\left(2400 \mathrm{~kg} \mathrm{ha}^{-}\right.$ 1) was observed under $\mathrm{N} @ 150 \mathrm{~kg} \mathrm{ha}{ }^{-1}$ (soil)+ Gillette (Micronutrients mixture) @ $2000 \mathrm{ml} \mathrm{ha}^{-1}$ (Foliar) as compared to N @ $100 \mathrm{~kg} \mathrm{ha}^{-1}$ (soil) + Gillette (Micronutrients mixture) @ $2000 \mathrm{ml} \mathrm{ha}^{-1}$ (Foliar) which was recorded $\left(2245.0 \mathrm{~kg} \mathrm{ha}^{-1}\right)$ seed yield. The crop was treated with $\mathrm{N} @ 150 \mathrm{~kg} \mathrm{ha}^{-1}$ (soil) + Gillette (Micronutrients mixture) @ 1250 $\mathrm{ml} \mathrm{ha}^{-1}$ (Foliar) produced (2100.00 kg ha ${ }^{-1}$ ) seed yield. The results further indicated that the crop was treated with $\mathrm{N} @ 50 \mathrm{~kg} \mathrm{ha}^{-1}$ (soil) + Gillette (Micronutrients mixture) @ $2000 \mathrm{ml} \mathrm{ha}^{-1}$ (Foliar) was showed (1990.0) seed yield. However, the crop treated with $\mathrm{N} @ 100 \mathrm{~kg} \mathrm{ha}{ }^{-1}$ (soil) + Gillette (Micronutrients mixture) @ $1250 \mathrm{ml} \mathrm{ha}^{-1}$ (Foliar) was observed (1896.7 kg ha $\left.{ }^{-1}\right)$ seed yield. Whereas the lowest seed yield (1700.3 $\left.\mathrm{kg} \mathrm{ha}^{-1}\right)$ was noted from control 
treatment. It is clear from the results that $\mathrm{N}$ @ $100 \mathrm{~kg} \mathrm{ha}^{-1}$ (soil) + Gillette (Micronutrients mixture) @ $2000 \mathrm{ml} \mathrm{ha}^{-1}$ (Foliar) recorded optimum results due to medium dose of nitrogen and nonsignificant differences (LSD @ 5\%) with $\mathrm{T} 7$ and T4 where highest dose of nitrogen was applied.

Table 3. Seed index (1000-seed weight, g) and seed yield ( $\left.\mathrm{kg} \mathrm{ha}^{-1}\right)$ of safflower as affected by nitrogen and micronutrients mixture (Gillette)

\begin{tabular}{|c|c|c|}
\hline \multirow[b]{2}{*}{ Treatments } & \multicolumn{2}{|c|}{ Mean } \\
\hline & $\begin{array}{l}\text { Seed index }(1000 \text {-seed } \\
\text { weight, } g)\end{array}$ & Seed yield $\left(\mathrm{kg} \mathrm{ha}^{-1}\right)$ \\
\hline $\mathrm{T}_{1}=$ Control (No $\mathrm{N}$ and micronutrient) & $39.0 \mathrm{E}$ & $1700.3 \mathrm{~F}$ \\
\hline $\mathrm{T}_{2}=\mathrm{N} @ 50 \mathrm{~kg} \mathrm{ha}^{-1}+$ Gillette@ $1250 \mathrm{ml} \mathrm{ha}{ }^{-1}$ & $39.2 \mathrm{E}$ & $1795.0 \mathrm{EF}$ \\
\hline $\begin{array}{c}\mathrm{T}_{3}=\mathrm{N} @ 100 \mathrm{~kg} \mathrm{ha}^{-1}+\text { Gillette@ } @ 1250 \mathrm{ml} \\
\mathrm{ha}^{-1}\end{array}$ & 40.0DE & 1896.7 DE \\
\hline $\begin{array}{c}\mathrm{T}_{4}=\mathrm{N} @ 150 \mathrm{~kg} \mathrm{ha}^{-1}+\text { Gillette } @ 1250 \mathrm{ml} \\
\mathrm{ha}^{-1}\end{array}$ & $42.0 \mathrm{BC}$ & $2100.0 \mathrm{C}$ \\
\hline $\mathrm{T}_{5}=\mathrm{N} @ 50 \mathrm{~kg} \mathrm{ha}^{-1}+$ Gillette@ $2000 \mathrm{ml} \mathrm{ha}^{-1}$ & $40.9 \mathrm{CD}$ & $1990.0 \mathrm{CD}$ \\
\hline $\begin{array}{c}\mathrm{T}_{6}=\mathrm{N} @ 100 \mathrm{~kg} \mathrm{ha}^{-1}+\text { Gillette@ } \\
\mathrm{ha}^{-1}\end{array}$ & $43.0 \mathrm{AB}$ & $225.0 \mathrm{~B}$ \\
\hline $\begin{array}{c}\begin{array}{c}\mathrm{T}_{7}=\mathrm{N} @ 150 \mathrm{~kg} \mathrm{ha}^{-1}+\text { Gillette } @ 2000 \mathrm{ml} \\
\mathrm{ha}^{-1}\end{array} \\
\end{array}$ & $44.0 \mathrm{~A}$ & $2400.0 \mathrm{~A}$ \\
\hline
\end{tabular}

\section{Discussion}

Micronutrients play different role for the plant growth, yield and enzyme activities but their deficiency may loss in crop growth and yield. It is seen from the results the maximum plant population $\left(42.2 \mathrm{~m}^{-2}\right)$ was observed under N@150 kg ha ${ }^{-1}$ (soil) + Gillette (Micronutrients mixture) @ 2000 $\mathrm{ml} \mathrm{ha}^{-1}$ (Foliar) as compared to N @ $100 \mathrm{~kg}$ ha $^{-1}$ (soil) + Gillette (Micronutrients mixture)@2000 ml ha ${ }^{-1}$ (Foliar)which was recorded $\left(41.1 \mathrm{~m}^{-2}\right)$ plant population. Whereas the lowest plant population (22.4 $\mathrm{m}^{-2}$ ) was showed in control treatment. The results revealed that the maximum plant height $(126.2 \mathrm{~cm})$ was observed under $\mathrm{N} @$ $150 \mathrm{~kg} \mathrm{ha}^{-1}$ (soil) + Gillette (Micronutrients mixture) @ $2000 \mathrm{ml} \mathrm{ha}^{-1}$ (Foliar) as compared to $\mathrm{N} @ 100 \mathrm{~kg} \mathrm{ha}^{-1}$ (soil) + Gillette (Micronutrients mixture) @ 2000 $\mathrm{ml} \mathrm{ha}^{-1}$ (Foliar) which was recorded (124.8 $\mathrm{cm})$ plant height. Whereas the lowest plant height $(96.1 \mathrm{~cm})$ was noted from control treatment. The results revealed that the maximum branches $\operatorname{plant}^{-1}(11.0)$ was observed under N@150 kg ha ${ }^{-1}$ (soil) + Gillette (Micronutrients mixture) @ 2000 $\mathrm{ml} \mathrm{ha}^{-1}$ (Foliar) as compared to N @ $100 \mathrm{~kg}$ ha $^{-1}$ (soil) + Gillette (Micronutrients mixture) @ $2000 \mathrm{ml} \mathrm{ha}^{-1}$ (Foliar)which was recorded (10.0) branches plant ${ }^{-1}$. The lowest branches plant ${ }^{-1}$ (7.0) was noted from control treatment. Foliar fertilization of micronutrients including $\mathrm{Zn}$ is very useful to fulfil the plant $\mathrm{Zn}$ requirement [12]. Similarly, B is another non-metal micronutrient essential required for proper plant growth and seed development [13]. Results showed that the maximum capitula plant $^{-1}$ (87.0) was observed under N @ 150 $\mathrm{kg} \mathrm{ha}^{-1}$ (soil) + Gillette (Micronutrients mixture) @ $2000 \mathrm{ml} \mathrm{ha}^{-1}$ (Foliar) as compared to $\mathrm{N} @ 100 \mathrm{~kg} \mathrm{ha}^{-1}$ (soil) + Gillette (Micronutrients mixture) @ 2000 $\mathrm{ml} \mathrm{ha}^{-1}$ (Foliar) which was recorded (85.0) capitula plant ${ }^{-1}$. However, the lowest capitula plant $^{-1}$ (73.0) was noted from control treatment. The results revealed that the maximum seed weight plant $^{-1}(164.2 \mathrm{~g})$ was observed under N@150 kg ha ${ }^{-1}$ (soil) + Gillette (Micronutrients mixture) @ 2000 $\mathrm{ml} \mathrm{ha}^{-1}$ (Foliar) as compared to N@100 kg $\mathrm{ha}^{-1}$ (soil) + Gillette (Micronutrients mixture)@2000 ml ha ${ }^{-1}$ (Foliar)which was recorded (153.4) seed weight plant ${ }^{-1}$. The lowest seed weight plant $^{-1}(70.7 \mathrm{~g})$ was noted from control treatment. The results revealed that the maximum seed index (44 
g) was observed in $\mathrm{T} 7$ at the rate of $\mathrm{N} @$ $150 \mathrm{~kg} \mathrm{ha}^{-1}$ (soil) + Gillette (Micronutrients mixture) @ $2000 \mathrm{ml} \mathrm{ha}^{-1}$ (Foliar) as compared to $\mathrm{N} @ 100 \mathrm{~kg} \mathrm{ha}^{-1}$ (soil) + Gillette (Micronutrients mixture) @ 2000 $\mathrm{ml} \mathrm{ha}^{-1}$ (Foliar) which was recorded (43.0 g) seed index. The lowest seed weight plant ${ }^{-1}$ $(39.0 \mathrm{~g})$ was noted from control treatment $\left(\mathrm{T}_{1}\right)$. Nitrogen is generally applied as broadcast to irrigated crops. However, micronutrients are mostly applied as foliar sprays [19]. The results revealed that the maximum seeds capitulum ${ }^{-1}$ (42.9 g) was observed under N@150 kg ha ${ }^{-1}$ (soil)+ Gillette (Micronutrients mixture) @ 2000 $\mathrm{ml} \mathrm{ha}^{-1}$ (Foliar) as compared to N @ $100 \mathrm{~kg}$ ha $^{-1}$ (soil) + Gillette (Micronutrients mixture) @ $2000 \mathrm{ml} \mathrm{ha}^{-1}$ (Foliar) which was recorded $(41.9 \mathrm{~g})$ seeds capitulum ${ }^{-1}$. Whereas the lowest seeds capitulum ${ }^{-1}(24.8$ g) was noted from control treatment. The results revealed that the maximum seed yield $\left(2400.0 \mathrm{~kg} \mathrm{ha}^{-1}\right)$ was observed under $\mathrm{N} @ 150 \mathrm{~kg} \mathrm{ha}{ }^{-1}$ (soil) + Gillette (Micronutrients mixture) @ $2000 \mathrm{ml} \mathrm{ha}^{-1}$ (Foliar) as compared to N@100 kg ha ${ }^{-1}$ (soil) + Gillette (Micronutrients mixture) @ $2000 \mathrm{ml} \mathrm{ha}^{-1}$ (Foliar) which was recorded $\left(2245.0 \mathrm{~kg} \mathrm{ha}^{-1}\right)$ seed yield. Similar results are reported by [18], they revealed that foliar application of micronutrients increased seed yield, number of heads, biological yield. Whereas the lowest seed yield $\left(1700.3 \mathrm{~kg} \mathrm{ha}^{-1}\right)$ was noted from control treatment [21], they concluded that foliar sprays of $0.2 \%$ borax, $0.4 \%$ ferrous sulphate, $0.5 \%$ zinc sulphate or $\mathrm{B}+\mathrm{Zn}$ applied to safflower 60 and 90 days after sowing gave seed yields of $880,753,695$ and $812 \mathrm{~kg} \mathrm{ha}^{-1}$, respectively compared with $765 \mathrm{~kg}$ with 2 water sprays and $635 \mathrm{~kg}$ in the untreated control.

\section{Conclusion}

It is concluded from the results that growth and yield of safflower was affected significantly $(\mathrm{P}<0.05)$ by the application of nitrogen and micronutrients mixture (Gillette). However, maximum seed yield (2400 $\mathrm{kg} \mathrm{ha}^{-1}$ ) was recorded in the integrated application of $\mathrm{N} @ 150$ kg ha ${ }^{-1}$ (soil) + Gillette (Micronutrients mixture) @ $2000 \mathrm{ml} \mathrm{ha}^{-1}$ (Foliar).

\section{Authors' contributions}

Conceived and designed the experiments: $\mathrm{Z}$ Ali \& WD Sipio, Performed the experiments: Z Ali, F Soomro, JA Khyber \& M Siyal, Analyzed the data: W Sahar \& J Kumar, Wrote the paper: MK Soothar \& SR Memon.

\section{References}

1. Morvarid G, Shirani AH, Delkhosh B \& Bitarafan Z (2012). Safflower (Carthamustinctorius L.) response to different nitrogen and phosphorus fertilizer rates in two planting seasons. J Plant Sci 65(2): 135-142.

2. Oelke EA, Oplinger ES, Teynor TM, Putnam DH, Doll JD, Kelling KA, Durgan BR \& Noetzel DM (2004). Extension Services, Departments of Agronomy, Plant Genetics and Entomology, Minnesota Extension Service, University of Minnesota, USA, pp 1-7.

3. Emongor V (2010). Safflower (Carthamus tinctoriusL.) the underutilised and neglected Crop: A Review. Asian J Plant Sci 9: 299-306.

4. Bassil ES, Kafka SR \& Hutmacher RA (2002). Response of safflower (Carthamus tinctoriusL.) to residual soil $\mathrm{N}$ following cotton in rotation in the San Joaquin Valley of California. $J$ Agri Sci 138: 395-402.

5. Galavi M, Ramroudi M \& Tavassoli A (2012). Effect of micronutrients foliar application on yield and seed oil content of safflower (Carthamus tinctorius). African J Agri Res 7(3): 482-486.

6. Scheppers JS \& Raun WR (2008). Nitrogen in Agricultural Systems. Agronomy Monograph no. 9. ASA/CSSA/SSSA, Madison.

7. Siddiqui MH \& Oad F (2006). Nitrogen requirement of safflower (Carthamus tinctorius L.) for growth and yield traits. Asian J Plant Sci 5(3): 563-565. 
8. Tilman D, Balzer C, Hill J \& Befort BL (2011). Global food demand and the sustainable intensification of agriculture. Proc Natl Acad Sci 108 (50): 20260-20264.

9. Quemada M, Baranski M, Mnj NL, Vallejo A \& Cooper JM (2013). Metaanalysis of strategies to control nitrate leaching in irrigated agricultural systems and their effects on crop yield. Agric Ecosyst Environ 174(2): 1-10.

10. Weil RR \& NC Brady. The nature and properties of soils. $15^{\text {th }}$ Ed. Pearson, England, pp 728-732.

11. Namvar H \& Khandan RZ (2015). Effect of drought stress and defoliation on sunflower (Helianthus annuusL.) in controlled conditions. Desert 12: 99104.

12. Asad A \& Rafique R (2000). Effect of zinc, copper, iron, manganese and boron on the yield and yield components of wheat crop in Tehsil Peshawar. Pak J Bio Sci 3(10): 18151820.

13. Sharma JC \& Chaudhary SK (2007). Vertical distribution of micronutrient actions in relation to soil characteristics in lower shivaliks of Solan district in North-West Himalayas. J Ind Soc Soil Sci 55: 40-44.

14. Singh RN, Prasad BK \& Singh NK (2002). Effect of lime and boron application to cotton in soil of Jharkhand. Indian J Agr Sci 72(6): 346347.

15. Rashid A (1996). Soil Science: Monitoring of soil fertility in Pakistan. National Book Foundation, Islamabad.

16. Gunes A \& Alpaslan M (2000). Boron uptake and toxicity in cotton genotypes in relation to boron and phosphorus supply. J Plant Nut 23(4): 541-550.

17. Marchner H (1995). Mineral nutrition of higher plants. $2^{\text {nd }} \mathrm{Ed}$. Academic Press. London.

18. Kohnaward P, Jalilian J \& Pirzad A (2012). Effect of foliar application of micro-nutrients on yield and yield components of safflower under conventional and ecological cropping systems. Int J Appl Basic Sci 3(7): 1460-1469.

19. Kilpatrick J (2013). Magnesium Sulfate for plant care. Home guides. Driven by Demand Median Hearst Newspaper.

20. Statistix (2006). Statistix 8 user guide, version 1.0. Analytical software, Tallahassee fl 32317 USA. Copyright @ 2006 by Analytical software.

21. Sangale PB, Patil GD \& Daftardar SY (2000). Effect of foliar application of zinc, iron and boron on yield of safflower. J Maharashtra Agric Uni 6(1): 65-66. 